\title{
垂れ壁の寸法や配置が仮想空間における空間中心位置の把握に与える影響 INFLUENCES OF SIZES AND POSITIONS OF HANGING WALL
ON PERCEPTION OF SPATIAL CENTER IN VIRTUAL REALITY SPACE
}

\author{
高橋勇 人*, 吉岡 陽介**
}

Hayato TAKAHASHI and Yohsuke YOSHIOKA

\begin{abstract}
This study aims to reveal influences of sizes and positions of hanging wall on perception of spatial center in immersive virtual space. In experiments, subjects wearing a wide-view head-mount-display were requested to move to a subjective central position of several virtual square rooms, on each of which a hanging wall was presented with specific size and position. Results indicated 1) Subjective central position could move backward from hanging walls by presenting hanging walls. 2) Subjective central position would move back more from hanging walls as the increasing heights of the hanging walls.
\end{abstract}

Keywords: Spatial Center, Virtual Space, Head-mounted-Display, Hanging Wall, Perception of Spatial Configuration 空間の中心，仮想環境ヘヘッドマウントディスプレイ，垂れ壁，空間形状の認識

\section{1 研究背景}

\section{1 はじめに}

日常生活をしていく上で人間は、様々な形状の空間を利用してい る。住宅の居間、職場の事務空間、学校の教室など、合目的的に作 られた空間の多くは、それぞれの用途に応じた必然的な空間形状を もっている。

空間内での人間の行動に影響を与えるこうした空間形状はしか し、界壁や床など、人間の行動範囲を物理的に制限する要素によっ てのみ規定されるものではない。床のテクスチヤ、壁面の凹凸、照 明照度の差など、微細な空間要素がつくり出す心理的境界が重なり 合い、空間内での人間の行動範囲を緩やかに分節することで、空間 固有のふるまいや行動規範が生み出されている。

個々の空間要素が作り出す心理的な境界の特性を理解し、室空間 内に計画的に配置することで、物理的には1つである室空間を適切 に分節し、より多彩な利用を促すことが可能になると考える。

本研究では、そうした空間要素のうち、垂れ壁のもつ心理的な境 界効果に着目する。垂れ壁が天井面に付加されても、人間の物理的 な行動範囲は大きくは制限されない。しかし垂れ壁によって、室空 間内にいる利用者の視線は部分的に遮られる。矩形の空間であれば、 天井の四隅や天井と壁の境界の一部が見えなくなり、室空間の全体 像がつかめなくなる。このような状況は空間形状の認識に少なから 影響を及ぼし、その空間でのふるまいを変化させると考える。

\section{2 各種の空間要素が空間形状の認識に及ぼす影響}

本研究では、垂れ壁の寸法や配置が空間形状の認識に及ぼす影響 を検証する。各種の空間要素が空間形状の認識にどのような影響を 及ぼすかについては、従来、多くの実験的研究が行われてきた。

内田の研究1,2)では、室空間に家具を配置したことによって生じる 空間の欠損効果を検証しており、家具の個数より、家具の置き方に よる影響のほうが大きいとした。同時に床面積や天井高など形状の 異なる空間の見た目の容積を数值で回答させており、物理容積が等 しい場合、床面積が小さく断面が縦長の室空間の方が、また長方形 よりも正方形平面の方が容積を大きく感じられるという結論を得 ている。

込山らの一連の研究3-5)では、「床面積を小さくした場合の容積の 減少分を、天井高を高くすることで補うことの可能性」の検証をし

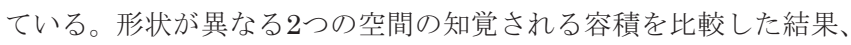
等容積であっても床面積の狭い、縦長断面の空間の方が最大 $10 \%$ 大 きく知覚される傾向があるとした。また、床段差が室空間の分節に 及ぼす影響についても検証しており 、床段差の差が $450 \mathrm{~mm}$ 以上に なると、空間は2つに感じられるようになるとしている。

橋本ら ${ }^{7)}$ や奥井ら ${ }^{8)}$ は、段差天井の段差幅や位置が室空間の印象評 価に与える影響を検証している。印象評価中「分節感」に関する評 価から、段差天井の段差幅が大きくなるに従い空間を $2 つ に$ 感じる 傾向が強まるとしている。

Grad. Stud., Graduate School of Engineering, Chiba University Assoc. Prof., Division of Architecture and Urban Science, Graduate School of Engineering, Chiba University, Dr.Eng.
* 千葉大学大学院工学研究科建築 ·都市科学専攻 博士前期課程

** 千葉大学大学院工学研究科建築 · 都市科学専攻 准教授・博士 (工学) 
これらの研究結果から、家具、床段差、段差天井といった空間要 素が、人間の空間形状の認識に影響を与えていることが分かる。本 研究では、こうした空間要素の一つとして、垂れ壁を扱う。

段差天井や床段差のような空間要素では、その付加によって空間 の物理的な容積が変化する。しかし垂れ壁であれば、空間を見通す 視線が部分的に遮られるだけで、利用できる空間の容積そのものは 大きくは変化しない。すなわち、人間の物理的な行動範囲を制限す ることなく、空間の利用目的に応じた適切な分節と使い分けを促す ことができるのである。

\section{3 空間分節要素としての垂れ壁}

近年、実際に住宅やオフィスに垂れ壁をデザインとして用いて空 間の使い分けを実践している事例がある 9-17)。住宅に垂れ壁を用い た事例では 9)、垂れ壁で囲まれた内側をLDK、外側を土間的な空間 とし、利用者の居場所や姿勢によって空間の感じ方を変化させる提 案がなされている。またオフィスに垂れ壁を用いた事例では 16)、カ フェテリアや会議室などで新しいコミュニケーションや空間の利 用を生み出されるように計画されている。こうした先進の事例にお ける垂れ壁は、防煙垂れ壁や構造上の梁など，空間の統一性を犠牲 にしながら消極的に付加されてきた旧来の垂れ壁とは異なり、空間 全体の統一性を保ちながら機能的に分節するためのデザイン要素 として積極的に利用されている。

本研究では、こうした空間分節要素として設けられる垂れ壁を念 頭に、天井面から垂れ下がり、かつ床面に接していない壁面ヴォリ ユームを、「垂れ壁」と総称することとし、住宅やオフィスといった 小規模な空間における「垂れ壁」の心理的効果を検証する。住宅や オフィスなど, 界壁で分断するには狭すぎる比較的小規模な空間に おいてこそ、垂れ壁による空間分節が大きな効果を発揮すると考え るからである。「垂れ壁」の寸法や配置の変化が、人間の空間形状の 認識に及ぼす影響を明らかにすることで、空間分節要素としての垂 れ壁の価值を再認し、空間デザインへの使用指針を提示したい。

\section{4 空間形状の認識と空間中心}

若山らによる屋外空間の「まとまり」評価18,19)では、「まとまり」 という言葉を評価軸として用いることで、空間を、界壁に囲まれた 物理的範囲としてではなく、心理的な広がりとして評価させること に成功している。実験では、対象として選定した屋外空間に、いく つかの評価地点を指定し、それぞれの地点から見える空間の「まと まり」を平面図と写真の上に記入させ、複数の被験者データを重ね 合わせることで屋外空間の心理的な広がりを定量化している。

実験の結果、各地点から見える空間要素の有無が、「まとまり」の 認識に影響を与えていることが明らかになった。特に、屋根や下が り天井など高さ方向の広がりを制限する空間要素がある場合は、制 限された下の部分の空間が一つのまとまりとして認識され、逆に、 高さを制限する空間要素がない場合は、評価地点から見える空間の うち平面的に最も広い空間が一つのまとまりとして認識されてい ることが明らかとなった。屋外空間の領域分析において「まとまり」 という新しい評価軸を導入したことは重要な着眼であり、参考とし たい。

本研究では、若山らの「まとまり」研究における心理的な空間形 状の評価軸のひとつである、「空間中心」を取り上げる。空間中心と は、空間を利用する者がさまざまな与件を総合的に判断した上で把
握する、心理的な空間の中心位置のことである。各種の空間要素を 配置することで、利用者が「まとまり」として捉える心理的な空間 の形状が変化するのであれば、心理的な空間の中心位置も、その空 間形状に応じた位置へと移動すると考える。

さらに、この空間の中心位置が、空間の幾何学的な空間中心に重 なるとすれば、その推移から逆算して、利用者によって認識される 空間形状の変化を推定し、各種の空間要素が分節にもたらす効果を 定量化することも可能である。

また本研究では、実験空間における空間中心を、実際にその中を 歩き廻りながら探し出し、最後にその位置に立ち止まることで被験 者自身にその位置を確定してもらう。若山らのまとまり計測が、空 間の外に視点を置いてひろがりを評価するものであったのに対し、 空間の中に身を置いて微調整しながら中心位置を探し出してもら うことで、空間要素の取捨による微細な空間形状の変化をより精緻 に計測することができると考える。

\section{5 仮想環境を用いた環境評価実験}

情報技術の発達に伴い、汎用的なデバイスでも、より現実に近い 仮想環境体験が可能になってきている。本研究では、Headmounted-Display（以下、HMD）を用いて、仮想環境の中に被験者 を没入させるかたちで環境評価実験を行う。

仮想環境を用いて環境評価実験を行うことの効果としては、以下 の3つが挙げられる。

まず、仮想環境であれば、最低限の仮想環境提示装置さえあれば、 どれだけ大規模な環境変化を比較する実験であっても、現実環境ほ ど大がかりな実験設備は不要である。また、現実環境での空間要素

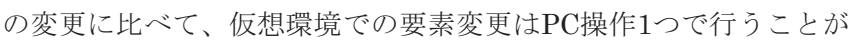
出来るため、実験時間を大幅に短縮し、被験者の身体的・精神的負 担を低減することができる。さらに、仮想環境では、仮想環境内に 提示する空間要素の寸法や配置などの各種プロパティを厳密な数 值でコントロール寸ることができるため、正確な実験条件の提示・ 変更が可能である。

逆に仮想環境を用いて環境評価実験を行うときに問題となるのは、 その現実環境に対する再現性であり、これまでに数多くの論考や検 証が行われてきている。

吉澤らの一連の研究20-22)では、仮想環境における実空間再現性を 評価するために仮想空間の高さ、幅、奥行などの寸法感について実 空間と同様に再現できるかを検証している。

実験は、大型スクリーン、液晶テレビ、ノートPCの、いずれも $\mathrm{CG}$ 映像を平面上に投影寸るタイプの提示装置を用いて実施されてい る。両眼視差による立体映像を画面に提示し、実空間との感覚の違 いを比較評価させる。結果、仮想環境は、高さや幅を実空間と同様 に再現されているが、奥行感など、室空間の広がりを感じづらいと 結論づけている。

同様に、平面投影型の仮想環境提示方法を調查の対象とした研究 として、横井ら ${ }^{23)}$ の仮想環境内での気分や寸法感の印象評価の研究 もある。結論としては吉澤らと同じく、スクリーンを用いた仮想環 境の提示方法では、奥行感を体感させるのは難しいとしている。

仮想環境の提示方法には、上記のようにCG映像をスクリーンなど に平面投影寸る方法20-23)のほかに、本研究で試みているような頭部 装着型のHMDを用いる方法24-30)がある。 
HMDを用いる利点としては、被験者の視覚を完全に覆うことがで きるため、平面投影に比べて被験者が感じる没入感が強いこと。眼 球とディスプレイの位置関係が変わらないため、視点移動による視 差が生じず、提示映像の感覚上のゆがみを常により小さく維持でき ることが挙げられる。

HMDを用いている研究としては、片山ら 25-27)が、縮尺模型と組み 合わせた視環境シミュレータの有効性の検証を行っている。被験者 に実空間を一定距離歩行させた後に、HMDを用いて映像のみを提 示した場合、HMDを用いて歩行動作に連動した映像を提示した場 合、実空間を再度歩行させる場合のそれぞれの提示方法において実 空間で歩行した距離を再現させたところ、映像のみを提示寸る距離 の知覚と比較して、歩行動作と連動した映像提示の方が、現実環境 における距離の知覚に近いことから、歩行動作を加えた仮想空間の 提示手法の有効性を確認している。

また、同様にHMDを用いた小野原や小場らの研究30,31)では、街路 の印象評価実験において、街路空間の CADモデルを作成し、3軸角 度センサーを組み合わせたHMDを用いて提示したところ、高い精 度で寸法感などの一致が見られている。また現実感に関するヒアリ ングでは、すべての被験者から高い現実感があると回答を得ており、 3軸角度センサーを組み合わせた HMDが仮想環境の体験装置とし て有効であることを確認している。

以上より、現実環境における寸法や距離の知覚が、HMDを用いた 仮想環境内においてある程度正確に再現されているものと考える ことができる。本論の検証はあくまで仮想環境に限定的なものでは あるが、将来的な現実の空間設計一の知見の援用の可能性も考慮し て、本研究においても同様のHMDを用いた手法を採用することと する。

なお、HMDによる仮想環境提示に残された技術的な問題としては、 被験者自身の身体が見えず臨場感が低下寸る原因になること。被験 者の頭の動きに対し映像処理が遅れることから生じる「酔い」など が挙げられる。後者の問題について本研究では、高性能な 3 軸角度セ ンサーと、より処理速度の速いワークステーションを映像提示に併 用することで解決を試みるとともに、被験者には事前に実験中は急 な頭部運動は避けるように指示をしている。

また本研究では、高精細カメラによる光学式トラッキングシステ ムをHMDと併用している。実験中の被験者の位置を、実空間の周囲 に設置した高精細カメラによって追跡し、正確な3次元座標位置に 合わせた仮想環境の映像をHMD内に提示することで、被験者は仮 想環境の中を自分の脚で歩き迴っているような感覚を得ることが できる。かつ、この光学式トラッキングシステムから得られる時系 列の被験者の位置の変化は、被験者の歩行軌跡そのものでもあり、 HMD映像の制御用以上に、実験データとしての豊富な情報をもつ。 実空間に、本研究で提示する垂れ壁のような遮蔽物を設置すると、 カメラの画角内に死角が生じてしまい、死角となる範囲にいる被験 者の座標を追跡できなくなってしまう可能性がある。このことから、 光学式トラッキングシステムは実空間より仮想環境での使用に適 したシステムであると言える。

\section{2 研究目的}

本研究では、矩形の仮想空間の中に、寸法や配置の異なる垂れ壁

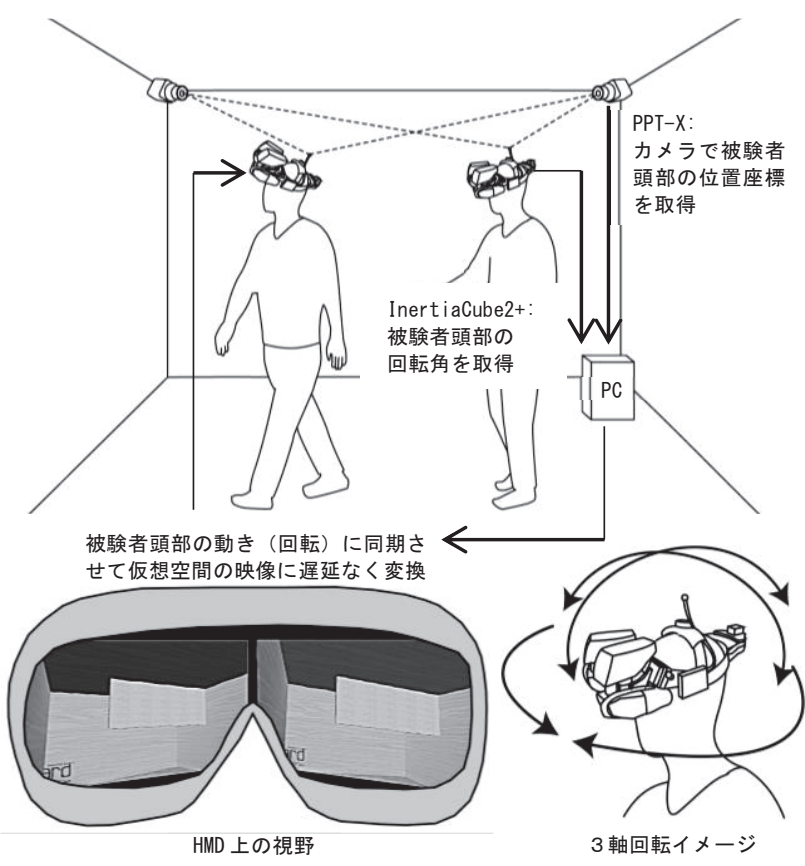

図 1 実験装置の概要
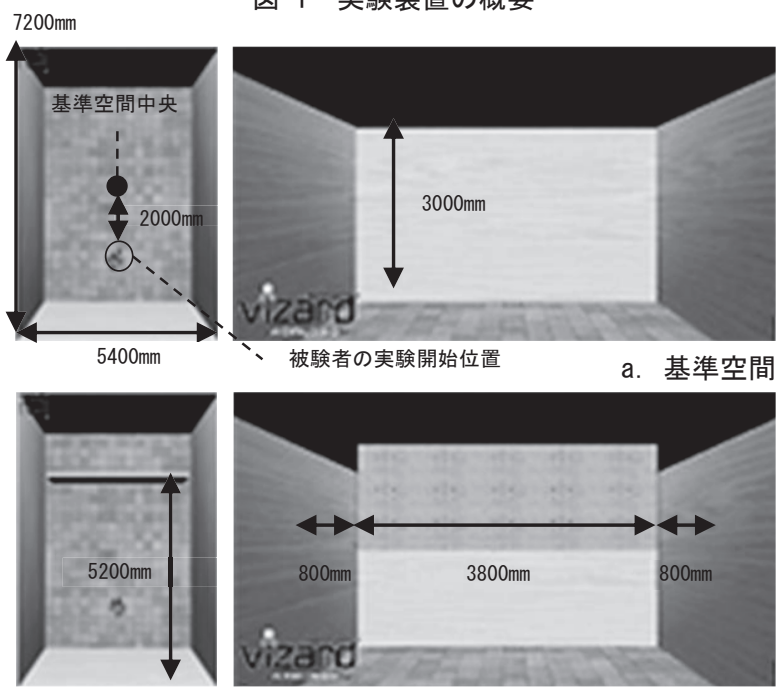

b. 左右型（中央）
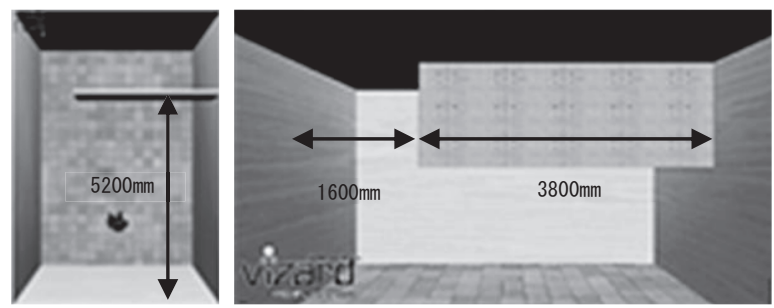

c. 左右型（右寄せ）
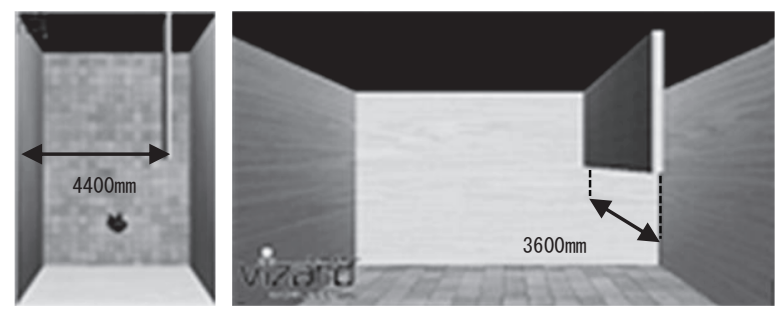

d. 前後型（左寄せ）

左：頭上からの俯瞰視点、右：実験開始位置からの視点

図 2 仮想空間における垂れ壁の配置パターン 
を提示し、被験者が認識する空間の中心位置の推移を測定する。そ のことによって、垂れ壁の寸法や配置の違いが仮想空間における空 間の中心位置の認識にどのような変化を及ぼすのかを検証する。

\section{3 実験方法}

本研究では、仮想現実技術を援用した被験者実験を行うことで、 垂れ壁がもつ効果の検証を行う。実験の概要は以下のとおりである。

\section{1 実験空間}

実験は、C大学の実験室 (幅 $7200 \mathrm{~mm} \times$ 奥行 $9000 \mathrm{~mm}$ ) にて行った。 VRソフトウェア：Vizard4.0（WORLD VIZ社製）を用いて、幅 $5400 \mathrm{~mm} \times$ 奥行 $7200 \mathrm{~mm} \times$ 高さ $3000 \mathrm{~mm}$ の仮想空間を作成した。仮 想空間の寸法は、本研究において対象とする住宅、オフィスのよう な小規模な空間と被験者が現実の実験室における移動範囲とを考 慮して設定した。天井と壁面は木目調、床はグレーのタイルをテク スチャとして割り当てている。本実験では、この仮想空間を基準空 間とし、さまざまな寸法と配置で垂れ壁を乗算して提示する。垂れ 壁には目地のあるコンクリートのテクスチャを割り当てている。

\section{2 実験機材}

被験者には、対角111度の広い視野角を備えたHMD（nVisor SX111:NVIS社製）を用い、仮想環境に没入してもらう。現実の実験 室の四隅には、ポジショントラッキング用のカメラ 4 台（PPTX:WORLD VIZ社製）が設置されており、実験中の被験者頭部の三 次元座標を追跡寸る。

またHMD後部には3 3 軸角度センサー (InertiaCube $2+$ ) が搭載さ れており、被験者頭部の回転角を取得する。この被験者頭部の座標 データおよび回転角データに対して、HMD内の仮想環境の映像を 遅延なく同調させることで、被験者は仮想環境内を自らの身体で、 歩き廻り見廻すことができる（図 1）。

\section{3 教示}

HMDを装着し仮想環境に没入している被験者に対し、「今、あな たのいる空間の中心まで歩いてください」との教示を与え、自身が 感じる空間の中心に自らの足で移動してもらう。被験者が最終的に 立ち止った位置の座標データを、その仮想空間に固有の中心位置と して取得する。垂れ壁の有無や寸法、配置を変化させることによる 中心位置の変異をもとに垂れ壁が空間形状の認識に与える影響を 検証する。なお被験者は、仮想空間内を自由に周遊し見回してよい こととし、側壁や垂れ壁に故意に衝突するような行為のみを禁止事 項とした。

\section{4 実験 I}

垂れ壁によって空間が視覚的に遮られると、被験者が認識する空 間形状には変化が生じると考える。また垂れ壁の寸法や配置によっ て空間の遮られ方は少しずつ変わるが、この変化に応じて心理的な 空間形状は変化し、空間の中心位置も移動すると考える。

実験 I では一連の研究の予備的な実験として、まず、仮想空間内 に垂れ壁を提示することで、被験者の判断する空間の中心位置が、 垂れ壁のない場合に比べて移動するかどうかを検証する。また垂れ 壁の寸法や配置の変化に対して空間の中心位置がどのように移動 するかを分析することで、空間の中心位置の移動パターンが、垂れ 壁によって生じる心理的な空間形状の変化をどのように反映して
いるのかを考察する。

なお、本研究では、基準空間の長方形平面に対して短辺に平行な 軸と長辺に平行な軸の 2 軸を設定し、それぞれ、被験者のスタート位 置を基準として、「左右方向」と「前後方向」と呼称することとする。 この呼称よって、垂れ壁を配置する方向と空間中心が移動する方向 を規定する。実験中に取得する被験者頭部の位置座標は、基準空間 の幾何学的な中央を始点にして、「左右方向」の右方向への移動が正 の数值、「前後方向」の垂れ壁から離れる方向への移動が正の数值、 として分析を行う。

\section{1 実験 I の実験条件および被験者}

被験者は、20代の大学生7名（男性5名、女性2名）とした。実験 I、 II ともに被験者は、HMDの使用経験がない学生を対象とする。

垂れ壁の高さは、被験者の平均身長（表 1）と同程度の垂れ壁下 部の「あき」寸法となる、高さ $1300 \mathrm{~mm}$ （「あき」1700mm）を基準 として、上下に $500 \mathrm{~mm}$ 変化させた、 $800 \mathrm{~mm} 、 1300 \mathrm{~mm} 、 1800 \mathrm{~mm}$ の 3 段階のとし、それぞれを以下の5種類の配置パターンで提示寸る。

まず、基準空間の左右方向に垂れ壁を配置した「左右型」と、前 後方向に配置した「前後型」に大別する（図 2)。

「左右型」では、左右壁面と垂れ壁両端との間に $800 \mathrm{~mm}$ の隙間を 設けた配置（1種類）と、片端のみ左右どちらかの壁面に接し、反対 側の壁面との間には $1600 \mathrm{~mm}$ の隙間を設けた配置 (2種類) の、配置 パターンがある。「左右型」では、いずれの配置パターンでも、垂れ 壁の幅は3800mmであり、基準空間中央から前後方向+1600mmの 位置に配置している。

「前後型」では、基準空間中央から左右に $1700 \mathrm{~mm}$ 移動した位置 に、片端が左右方向の壁面に接するように垂れ壁を片寄せて配置し ている (2種類)。「前後型」は、2種類の配置パターンともに、垂れ 壁の幅は、3600mmである。

実験開始時の被験者の立ち位置は、基準空間の中央から前後方向 -2000mmの位置とした。

実験の試行は、垂れ壁を付加しない基準空間と垂れ壁を付加した 空間を順番に計16回行う。被験者に空間の広さや形状などを正しく 認識させるため、試行ごとにVR空間内を自由に周遊した後に、中心 位置まで歩いてもらった。

表 1 実験 I ・ II の被験者の身長

\begin{tabular}{|c|c|c|c|}
\hline \multicolumn{2}{|l|}{ 実験 I } & \multicolumn{2}{|l|}{ 実験 II } \\
\hline 被験者 & 身長 [m] & 被験者 & 身長 [m] \\
\hline №.01 & 1.65 & N01 & 1.71 \\
\hline №.02 & 1.79 & N02 & 1.83 \\
\hline №.03 & 1.83 & N03 & 1.73 \\
\hline No.04 & 1.67 & N04 & 1.71 \\
\hline №.05 & 1. 72 & N05 & 1.67 \\
\hline №.06 & 1. 75 & N06 & 1.65 \\
\hline \multirow[t]{5}{*}{ №.07 } & 1.74 & N07 & 1.65 \\
\hline & & N08 & 1. 70 \\
\hline & & N09 & 1.82 \\
\hline & & N010 & 1.64 \\
\hline & & N011 & 1.60 \\
\hline 平均 & 1. 74 & 平均 & 1.70 \\
\hline
\end{tabular}




\section{2 実験 I の結果と考察}

空間の中心位置の移動距離について、垂れ壁の寸法、配置条件を 要因とした分散分析を行い、主効果あるいは単純主効果が確認され た条件について、ボンフェローニ法による多重比較検定 (1％水準) の結果を拾った。本論では実験 I 、実験 II の考察を通じて、以下同 様の手法で統計分析を行うものとする。

空間中心の移動の分析はまず、前後方向への変化量、つづいて、 左右方向への変化量に分けて行う。その後、2軸の変化量を統合し、 空間中心の移動方向についての考察を行う。

\section{2. 1 左右型の垂れ壁配置による前後方向への空間中心の移動}

「左右型」の垂れ壁による前後方向への空間中心の移動について、 垂れ壁の配置と高さを要因とした分散分析を行ったところ、垂れ壁 の高さについてのみ主効果が認められた。そこで垂れ壁の高さにつ いての多重比較を行ったところ、基準空間での空間中心と、各寸法 の垂れ壁を提示した場合の空間中心との間に、有意な差 $(\mathrm{p}<0.001)$ が認められた (図 3)。矩形空間の短辺方向に垂れ壁を提示すること で、垂れ壁がないときに比心゙、空間中心が、垂れ壁を正面にして後 ろ向きに移動することが確認できた。

続いて、垂れ壁の高さが、前後方向への空間中心の移動に与える 影響を検証する。

垂れ壁を空間の中央軸上に配置した「左右型：中央」では、高さ $800 \mathrm{~mm}$ の垂れ壁を提示した場合の空間中心と、高さ $1800 \mathrm{~mm}$ の垂れ 壁を提示した場合の空間中心との間に、有意な差が認められた ( $\mathrm{p}<0.001$ 、図 3)。また高さ1300mmと1800mmの垂れ壁の間にも、 有意な空間中心の移動が認められた $(\mathrm{p}=0.005$ 、図 3$)$ 。

同様に、垂れ壁を左あるいは右に片寄せて配置した「左右型 : 左」 と「左右型 : 右」の条件でも、高さ $800 \mathrm{~mm}$ と $1800 \mathrm{~mm}$ の垂れ壁との 間、高さ $1300 \mathrm{~mm}$ と $1800 \mathrm{~mm}$ の垂れ壁との間に、それぞれ有意な空 間中心の移動が認められた $(\mathrm{p}<0.001 、 \mathrm{p}<0.001 、 \mathrm{p}<0.001 、 \mathrm{p}<0.001$ 、 図 3)。

以上より、矩形の空間の短辺方向に垂れ壁を配置した場合、垂れ 壁の高さが1800mmになると、空間中心が、垂れ壁を正面にして後 ろ向きに大きく移動することが確認できた。

\section{2. 2 左右型の垂れ壁配置による左右方向への空間中心の移動}

「左右型」の垂れ壁による左右方向への空間中心の移動について、 垂れ壁の配置と高さを要因とした分散分析を行ったところ、二要因 の交互作用が認められた。そこで単純主効果の確認された垂れ壁の 高さについてのみ多重比較を行ったところ、高さ $1800 \mathrm{~mm}$ の垂れ 壁を提示した場合の空間中心と、垂れ壁のない基準空間の空間中心 との間にそれぞれ有意な差（ $<<0.001 、 p=0.021$ 、図 4) が認められ た。特に「左右型：左」では、高さ $800 \mathrm{~mm}$ と $1300 \mathrm{~mm}$ の垂れ壁の 提示した条件についても、基準空間に比べて、空間中心が左右方向 に移動することが確認できた（ $=0.026 、 p<0.001 ） 。$

なお空間の左右に垂れ壁を片寄せて配置した「左右型 : 左」と「左 右型：右」では，空間中心はいずれも垂れ壁を片寄せた方向へ偏っ て移動する傾向が見られた。移動量を定量的に比較するため、ここ では、左方向への空間中心の移動が見られた「左右型：左」の計測 值について、符号を反転して分析することとした。

以上のことから、矩形の空間の中央軸に対して、左右のどちらか に片寄せて垂れ壁を配置することで、空間中心が垂れ壁を片寄せた

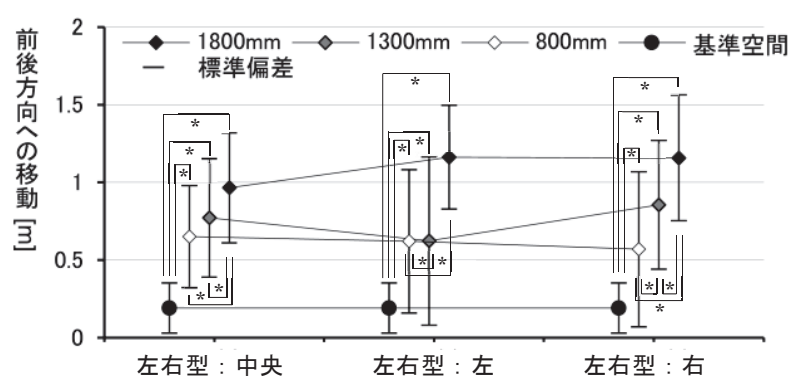

図 3 「左右型」配置の前後方向への空間中心の移動

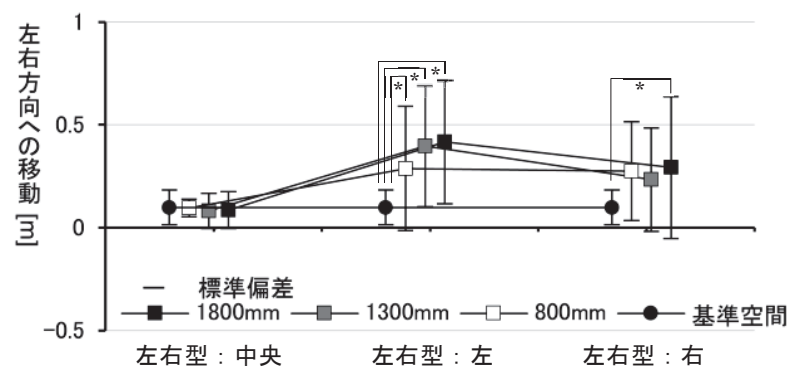

図 4 「左右型」配置の左右方向への空間中心の移動

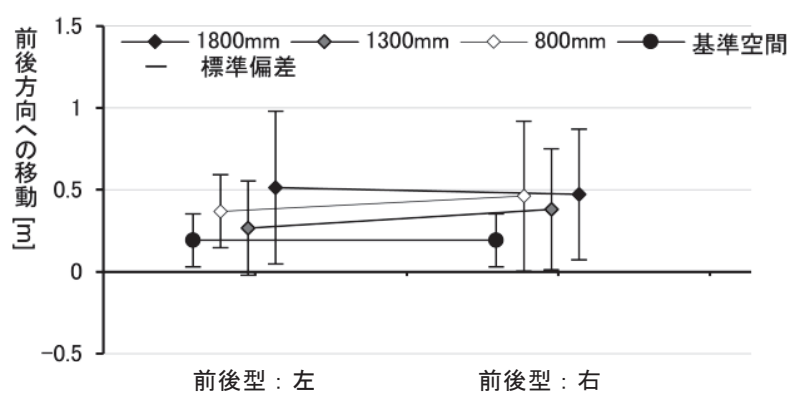

図 5 「前後型」の前後方向への空間中心の移動距離

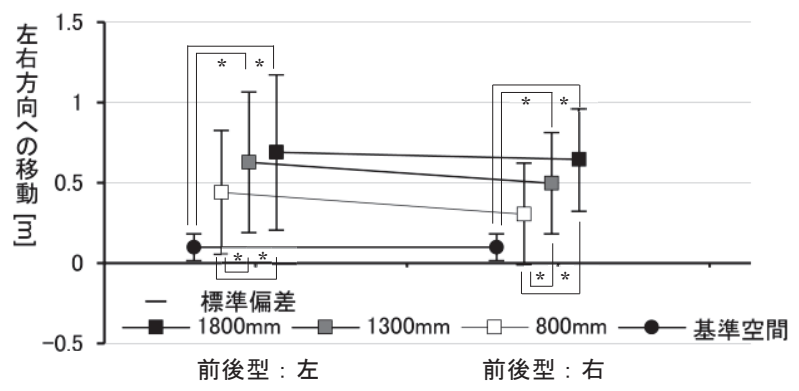

図 6 「前後型」の左右方向への空間中心の移動距離

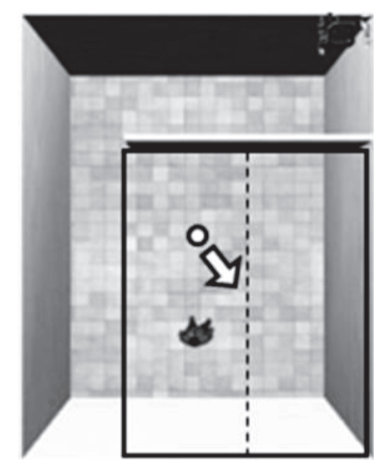

a. 「左右型」配置

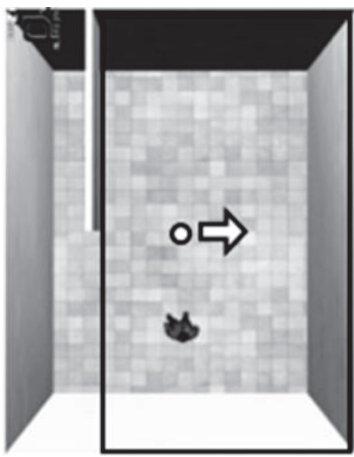

b.「前後型」配置
図 7 空間中心の移動から推測できる空間形状 
方向に向かって移動することが確認できた。ただし片寄せて垂れ壁 を配置しても空間中心が左右に偏らない被験者も見られた。

\section{2.3 前後型の垂れ壁配置による前後方向への空間中心の移動}

続いて、矩形空間の前後方向に垂れ壁を配置した「前後型」にお ける空間中心の移動について分析を行う。まず前後方向への空間中 心の移動について、垂れ壁の配置と高さを要因とした分散分析を行 ったところ、いずれの要因についても有意な主効果・交互作用は認 められなかった。「前後型」の垂れ壁配置における前後方向への移動 の結果を図 5 に示す。

以上より、垂れ壁を、矩形空間の長辺方向の中央軸に対して、片 寄せて配置した場合には、前項で観察した、短辺方向の中央軸に対 して片寄せて配置した場合とは異なり、垂れ壁に平行な方向への空 間中心の移動は発生しないことがわかる。

この結果の差異は、空間の幅に対する垂れ壁の幅が占める割合の 違いによって生じたのではないだろうか。「左右型」の片寄せ配置で は、空間の幅に対して垂れ壁の幅が占める割合が大きい。それに対 して「前後型」配置では、空間の幅に対する垂れ壁の幅が占める割 合はちょうど半分になっている。

\section{2.4 前後型の垂れ壁配置による左右方向への空間中心の移動}

「前後型」配置の垂れ壁による左右方向への空間中心の移動につ いて、垂れ壁の配置と高さを要因とした分散分析を行ったところ、 垂れ壁の高さについてのみ主効果が認められた。

多重比較の結果、「前後型 : 左」と「前後型 : 右」の条件では、基 淮空間の空間中心と高さ $1300 \mathrm{~mm}$ の垂れ壁を提示した場合の空間中 心との間にそれぞれ有意な差 $(\mathrm{p}<0.001)$ が認められた。同様に基準 空間の空間中心と高さ $1800 \mathrm{~mm}$ の垂れ壁を提示した場合の空間中心 との間にそれぞれ有意な差 $(\mathrm{p}<0.001)$ が認められた（図 6)。矩形 の空間の長辺方向に垂れ壁を配置することで、垂れ壁がないときに 比へ、空間中心が垂れ壁を正面にして後ろ向きに移動することが確 認できた。

なお「前後型 : 左」と「前後型 : 右」では、空間中心が垂れ壁を正 面にして後ろ向きに移動する傾向が見られた。4.2.2 と同様、移動量 を定量比較するため、左方向への移動が見られた「前後型：左」の 計測值について、符号を反転して分析することとした。

続いて、垂れ壁の高さが変化することによる左右方向への空間中 心の移動を分析する。「前後型 : 左」配置の垂れ壁では、垂れ壁の高 さが、 $800 \mathrm{~mm}$ と $1300 \mathrm{~mm}$ との間、 $800 \mathrm{~mm}$ と $1800 \mathrm{~mm}$ との間に、 それぞれ有意な差 $(\mathrm{p}=0.005 、 \mathrm{p}<0.001)$ が認められた。また「前後 型：右」配置の垂れ壁でも、垂れ壁の高さが、 $800 \mathrm{~mm}$ と $1300 \mathrm{~mm}$ との間、 $800 \mathrm{~mm}$ と $1800 \mathrm{~mm}$ との間に、それぞれ有意な差 $(\mathrm{p}=0.004$ 、 $\mathrm{p}<0.001$ ）が認められた（図 6)。

以上より、矩形の空間の長辺方向に垂れ壁を配置した場合、垂れ 壁の寸法が高くなるに従い短辺方向への空間中心の移動量が大き くなることが確認できた。しかし、「前後型 : 左」と「前後型 : 右」 のどちらの配置においても、垂れ壁の高さが $1300 \mathrm{~mm}$ の場合と $1800 \mathrm{~mm}$ の場合との間には、有意な差が認められなかった。

以上のことから、垂れ壁の高さが高くなるにつれて、空間中心の 移動量は次第に増加していくが、垂れ壁の高さが一定の值を超える とそれ以上移動量は増加しなくなる、ことが確認できた。垂れ壁の 高さには、ある一定の高さを超えるとそれ以上空間中心が動かなく
なるような、閾值があると考えられる。実験 II では、この垂れ壁高 さの闇值がどの範囲にあるのかを探ることとする。

\section{2.5 垂れ壁を片寄せて配置した場合の空間中心の移動方向}

次に、垂れ壁を片寄せて配置した場合の、空間中心の移動する「方 向」について分析する。左右方向と前後方向の空間中心の移動量を 統合して分析した結果、次の二つの傾向が見られた（図 7)。

a）「左右型」配置で、垂れ壁を左右どちらかに片寄せると、空間 中心も、提示した垂れ壁の中央の軸に近づくように斜めに後退寸る。 b）「前後型」配置では、垂れ壁を左右に片寄せても、空間中心は どちらにも偏ることなく提示した垂れ壁に対して垂直に後退する。 つまり、同じように垂れ壁を片寄せて配置しても、「左右型」と「前 後型」配置では、垂れ壁に対する空間中心の移動する方向が異なる のである。この移動方向の差異は、空間の幅に対して垂れ壁の幅が 占める割合の違いによって生じたものと考えることはできないか。

「左右型」の片寄世配置では、空間の幅に対して垂れ壁の幅が占 める割合が大きい。この割合の垂れ壁を提示することによって、被 験者は、目の前の空間の形状を、垂れ壁の幅を全幅とする小さな矩 形の空間として認識するようになったのではないかと考える。

垂れ壁の幅を全幅とする小さな矩形空間を想定した場合、その幾 何学的な中心位置は、基準空間中央から左右方向へ $0.8 \mathrm{~m}$ 、前後方向 $1.0 \mathrm{~m}$ セットバックした位置になる。実際、被験者の心理的な空間中 心は、この幾何学的な中心位置へ近づく結果となっている。

それに対して「前後型」配置では、空間の幅に対する垂れ壁の幅 が占める割合はちょうど半分である。この割合の垂れ壁を提示する ことによって、被験者が認識する空間の形状は、垂れ壁の延長線と 三方の壁面によって囲まれた矩形の形状へと変化したのではない だろうか。この空間形状の幾何学的な中心位置は、垂れ壁に垂直な 方向へ $0.5 \mathrm{~m}$ セットバックした位置になるが、実験結果より示され た心理的な空間中心は、次第にこの位置へ近づいている。

基準空間に対する垂れ壁の幅の占める割合によって、被験者の認 識する空間形状の大枠が変化し、空間中心の移動方向が決定されて いるのではないか。実験 II ではこの点を検証課題の 1 つとする。

表 2 垂れ壁の寸法 $[\mathrm{mm}]$ と配置条件（実験 II）

\begin{tabular}{|c|c|c|}
\hline & (1)高さ寸法の変化 & (2)幅の割合の変化 \\
\hline 基準空間 & \multicolumn{2}{|c|}{$5400 \times 7200$} \\
\hline 垂れ壁の配置 & 基準空間の中央軸上 & 右側の壁に片寄せ \\
\hline 垂れ壁の幅 & 5400,3600 & 3600,1800 \\
\hline \multirow[t]{2}{*}{ 垂れ壁の高さ } & $0,500,1000,1500$ & $0,500,1500,2500$ \\
\hline & $2000,2500,3000$ & \\
\hline 実験条件数 & 14 & 8 \\
\hline
\end{tabular}

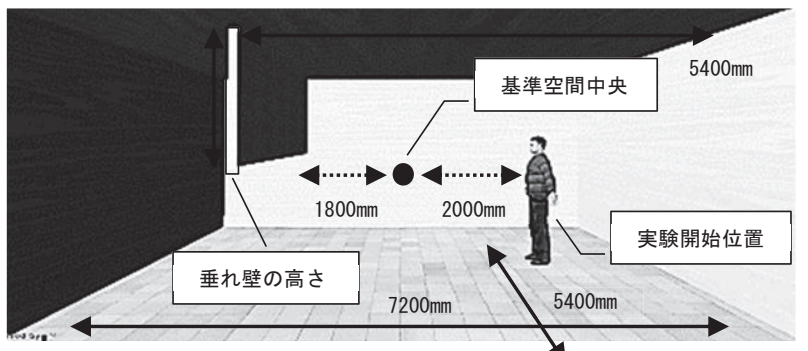

図 8 仮想空間の寸法と被験者の位置関係（実験 II） 
実験 I より、矩形の仮想空間に垂れ壁を配置することで被験者の 判断する空間の中心位置が、垂れ壁のない場合に比べて有意に移動 することがわかった。また、垂れ壁が高くなるにしたがって、空間 中心の移動量が次第に増加していくこともわかった。このことから、 被験者の判断する空間の中心位置の座標やその移動が、垂れ壁によ って生じる心理的な空間形状の変化、特に空間の分節の程度を評価 する空間指標の一つとして用いることができると考える。

しかし実験 I では同時に、垂れ壁がある高さを超えると空間中心 の移動量が増加しなくなる傾向も見られた。垂れ壁の高さには、一 定の值を超えるとそれ以上空間中心が動かなくなるような、閾值が あると考える。また、垂れ壁を片側の壁に寄せて配置した空間では、 空間中心も左右に偏る傾向が見られた。この空間中心の偏りは、基 準空間の幅に対して垂れ壁の幅が占める割合によって説明できる と考える。実験 II では上記の 2 点について詳細な検証を行う。

\section{1 実験 Iの実験条件および被験者}

被験者は20代の大学生 12 名（男性9名、女性 3 名）である。

実験 II は、(1)垂れ壁高さの細かな寸法設定が空間中心の移動に与 える影響の検証と(2)垂れ壁の幅の基準空間の幅に対する割合が空 間中心の移動に与える影響の検証の 2 種類で構成される（表 2)。

(1)の垂れ壁高さの影響の検証では、500 $\mathrm{mm}$ から3000mmまでを $500 \mathrm{~mm}$ 刻みで分割した、6段階の高さの垂れ壁を用意した。垂れ壁 の幅は $3600 \mathrm{~mm}$ と $5400 \mathrm{~mm}$ の 2 種類、空間の中央軸上に左右対称に 配置している。

(2)の垂れ壁幅の影響の検証では、3600mm と $1800 \mathrm{~mm}$ の幅の垂れ 壁を用意し、右側の壁に片寄せて配置する。この検証での垂れ壁高 さは、 $500 \mathrm{~mm} 、 1500 \mathrm{~mm} 、 2500 \mathrm{~mm}$ の3段階のみとする。

垂れ壁は、いずれも基準空間中央から前後方向+1800mmの位置の 左右方向に配置した (図 8)。被験者が空間中心の移動軌跡を意識し てしまうのを避けるため垂れ壁の寸法の変化はランダムとした。

\section{2 実験 IIの結果と考察}

\section{2.1 垂れ壁の高さによる前後方向への空間中心の移動}

まず(1)垂れ壁高さの影響の検証について、中央配置された垂れ壁 の高さが、前後方向への空間中心の移動に与える影響を分析する。

垂れ壁の幅と高さを要因として分散分析を行ったところ、垂れ壁 の高さについてのみ主効果が認められた。多重比較の結果、基準空 間との比較では、幅 $3600 \mathrm{~mm}$ と幅 $5400 \mathrm{~mm}$ のどちらの垂れ壁でも、 高さ $500 \mathrm{~mm}$ の垂れ壁を配置した場合の空間中心と、基準空間の空 間中心との間にそれぞれ有意な差 $(\mathrm{p}=0.002 、 \mathrm{p}=0.018)$ が認められ た。同様に高さ $1000 \mathrm{~mm}$ 以上の垂れ壁を配置した場合の空間中心 と、基準空間の空間中心との間にも、それぞれ有意な差が認められ た（p<0.001、図 9)。

続いて、垂れ壁の高さの変化による、前後方向への空間中心の移 動量の増減を分析する。

幅3600mmの垂れ壁では、垂れ壁高さ500mmに対しては、垂れ壁 高さ $2000 \mathrm{~mm} 、 2500 \mathrm{~mm} 、 3000 \mathrm{~mm}$ における空間中心が、垂れ壁高 さ $1000 \mathrm{~mm}$ と $1500 \mathrm{~mm}$ に対しては、垂れ壁高さ $2500 \mathrm{~mm} 、 3000 \mathrm{~mm}$ の空間中心が、それぞれ有意に移動していた（ $\mathrm{p}=0.002 、 \mathrm{p}<0.001$ 、 $\mathrm{p}<0.001 、 \mathrm{p}=0.029 、 \mathrm{p}<0.001 、 \mathrm{p}<0.001 、 \mathrm{p}=0.001$ 、図 9)。

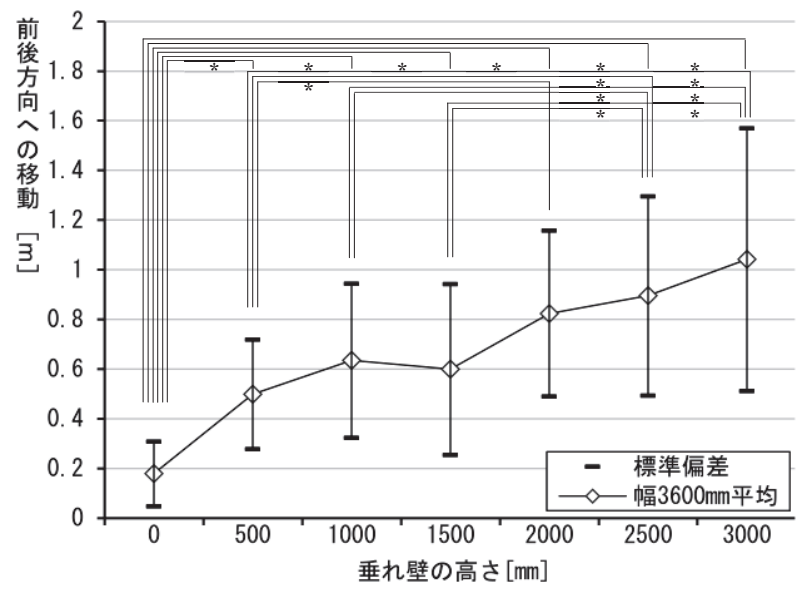

図 9 幅 $3600 \mathrm{~mm}$ による前後方向への空間中心の移動

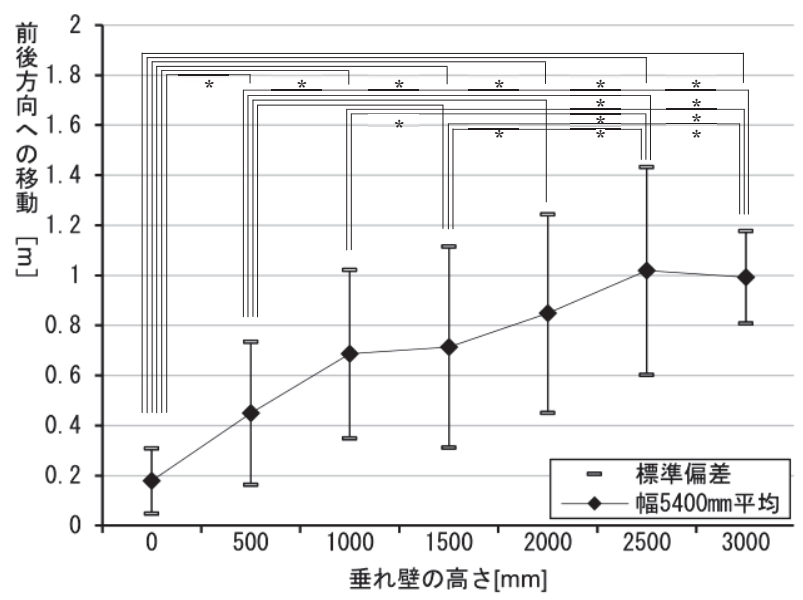

図 10 幅 $5400 \mathrm{~mm}$ による前後方向への空間中心の移動

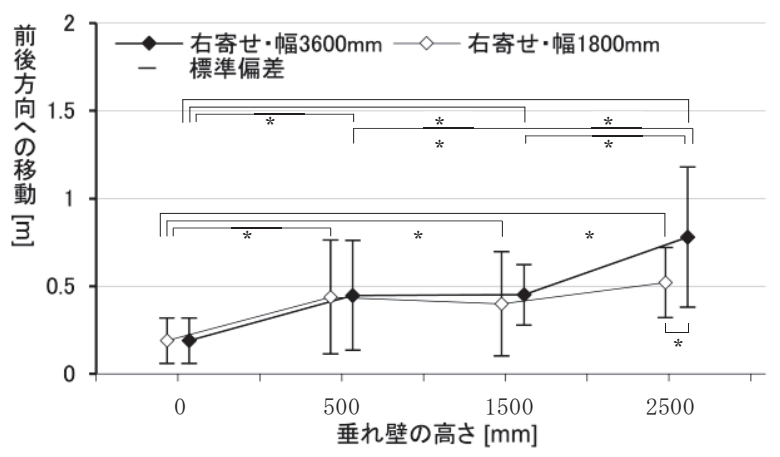

図 11 垂れ壁の幅の影響による前後方向への空間中心の移動

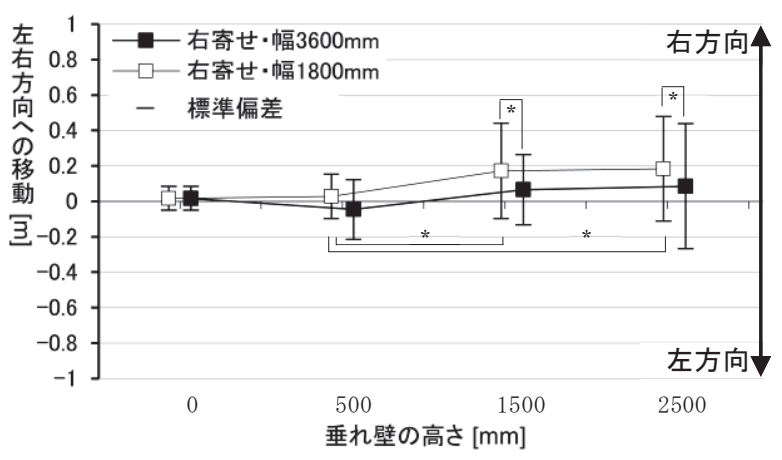

図 12 垂れ壁の幅の影響による左右方向への空間中心の移動 
また幅5400mmの垂れ壁では、垂れ壁高さ500mmに対しては、垂 れ壁高さ $1500 \mathrm{~mm} 、 2000 \mathrm{~mm} 、 2500 \mathrm{~mm} 、 3000 \mathrm{~mm}$ におる空間中 心が、垂れ壁高さ $1000 \mathrm{~mm} 、 1500 \mathrm{~mm}$ に対しては、垂れ壁高さ $2500 \mathrm{~mm} 、 3000 \mathrm{~mm} に お け る$ 空間中心が、それぞれ有意に移動して いた（p=0.025、p<0.001、p<0.001、p<0.001、p=0.001、p=0.004、 $\mathrm{p}=0.004 、 \mathrm{p}=0.014$ 、図 10)。

すなわち、幅 $3600 \mathrm{~mm}$ と幅 $5400 \mathrm{~mm}$ の垂れ壁では、どちらも高さ $1500 \mathrm{~mm}$ と $2500 \mathrm{~mm}$ の間において、有意な空間中心の移動が起こっ ている。一方で、高さ $2000 \mathrm{~mm}$ 以上の垂れ壁の間では、空間中心の 有意な移動は確認できない。このことから、空間中心をより大きく 移動させるには、2000 mmから $2500 \mathrm{~mm}$ 程度の垂れ壁を適切に配置 寸ることで十分な効果が期待できるといえる。

以上のことから、垂れ壁高さが2000 $\mathrm{mm}$ から $2500 \mathrm{~mm}$ の間にある 閾值を超過した時点で、被験者の認識する空間形状がある程度決定 されたと考えられる。閾值以上の高さの垂れ壁を配置することで、 適度な繋がりを保ちながら、上下全幅の壁面を配置するのと同程度 の大きさに、空間を分節することができるといえる。

\section{2.2 垂れ壁の高さによる左右方向への空間中心の移動}

(1)垂れ壁高さの影響の検証について、垂れ壁の幅と高さを要因と して、左右方向への空間中心の移動について分散分析を行ったとこ ろ、いずれの要因についても主効果は認められなかった。

\section{2.3 垂れ壁の幅による前後方向への空間中心の移動}

続いて、(2)垂れ壁幅の影響の検証について、片寄せ配置の垂れ壁 の幅が、前後方向への空間中心の移動に与える影響を分析する。

垂れ壁の幅と高さを要因とした分散分析の結果、二つの要因それ ぞれに主効果が認められた。そこで垂れ壁の高さについての多重比 較を行ったところ、各高さ寸法の垂れ壁を提示した場合の空間中心 と、基準空間の空間中心との間に、それぞれ有意な差が認められた （p<0.001、図 11）。幅3600mmと幅1800 mmのどちらの垂れ壁で も、空間中心は垂れ壁を正面にして後退するように移動している。

垂れ壁の高さの変化による、前後方向への空間中心の移動量の増 減を分析したところ、幅 $3600 \mathrm{~mm}$ の垂れ壁を片寄せて配置した条件 では、前節で検証した中央軸上配置における空間中心の移動と同様、 垂れ壁高さ $500 \mathrm{~mm}$ と $2500 \mathrm{~mm}$ との間、 $1500 \mathrm{~mm}$ と $2500 \mathrm{~mm}$ との間に、 それぞれ有意な空間中心の移動が認められた（p<0.001）。しかし同 じ片寄せ配置でも、幅 $1800 \mathrm{~mm}$ の垂れ壁では、垂れ壁高さの変化に よる空間中心の有意な移動は認められなかった（図 11）。このこと から、同じように片寄せ配置した垂れ壁でも、垂れ壁の幅によって、 前後方向への空間中心の移動の様相に違いがあることがわかる。ま た垂れ壁の幅を要因とした多重比較からは、垂れ壁高さ $2500 \mathrm{~mm} に$ おいてのみ、幅 $3600 \mathrm{~mm}$ と幅 $1800 \mathrm{~mm}$ の垂れ壁の間に有意な前後方 向への空間中心の移動が確認された（ $\mathrm{p}<0.001$ 、図 11）。

以上より、矩形空間に垂れ壁を片寄せて配置する場合、矩形空間 の幅に対する垂れ壁の幅の割合が小さいときには、垂れ壁に直行す る方向への空間中心の移動量は、垂れ壁の高さによって大きく変化 することはなく、逆に、垂れ壁の幅の割合が大きいときには、垂れ 壁の高さに応じて、全幅の垂れ壁を提示した場合と類似した空間中 心の移動推移をみせることが分かった。

\section{2.4 垂れ壁の幅による左右方向への空間中心の移動}

(2)垂れ壁幅の影響の検証について、片寄せ配置の垂れ壁の幅が、

左右方向への空間中心の移動に与える影響を分析する。

まず垂れ壁の幅と高さを要因として分散分析を行ったところ、二 要因それぞれに主効果が認められた。

そこで垂れ壁の高さについての多重比較を行ったところ、基準空 間との比較では、幅 $1800 \mathrm{~mm}$ の垂れ壁についてのみ、高さ $1500 \mathrm{~mm}$ と高さ $2500 \mathrm{~mm}$ の条件における空間中心と、基準空間の空間中心と の間に有意な差が認められた（ $\mathrm{p}<0.001$ 、図 $12 ） 。$

また垂れ壁高さの変化による空間中心の移動量の増減について も、幅 $1800 \mathrm{~mm}$ の垂れ壁においてのみ、高さ $500 \mathrm{~mm}$ と $1500 \mathrm{~mm}$ 、高 さ $500 \mathrm{~mm}$ と $2500 \mathrm{~mm}$ の間で、それぞれ有意な空間中心の移動が認め られた（p<0.001、 $\mathrm{p}<0.001$ 、図 12）。一方、幅3600mmの垂れ壁 では、どの条件間においても、基準空間との比較においてさえも、 左右方向への空間中心の有意な移動は認められなかった。

また、垂れ壁の幅についての多重比較からは、幅 $3600 \mathrm{~mm}$ と幅

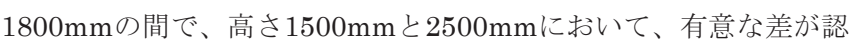
められた（ $\mathrm{p}=0.009 、 \mathrm{p}=0.018 ） 。$

以上より、垂れ壁を片寄せて配置する場合、矩形空間の幅に対す る垂れ壁の幅の割合が小さいときには、垂れ壁の高さに応じて、垂 れ壁に平行する方向への空間中心の移動が生じることが分かった。 逆に割合が大きいときには、垂れ壁のない場合と比較しても、垂れ 壁に平行する方向への空間中心の移動は生じないことが分かった。

ただし、幅1800mmの垂れ壁では、垂れ壁を片寄せた側と反対方 向に、空間中心は移動している。また実験 I では、垂れ壁の幅が大 きい場合にも空間中心が移動しており、その移動方向は垂れ壁を片 寄せた側と同一方向であった。垂れ壁と平行な方向への空間中心の 移動に関しては、垂れ壁の幅以外の要素も絡んでいる可能性がある。

\section{2. 5 空間中心の移動から推測できる空間形状}

前章と同様に本章においても、空間中心の移動量と移動方向から、 被験者が認識しているであろう空間形状の推定を試みる。

まず(1)垂れ壁高さの影響の検証において見られた、前後方向と左 右方向の空間中心の移動量を統合し分析する。

どの条件においても左右方向への空間中心の移動は見られなか った。垂れ壁を中央軸上に配置した場合には、空間中心は、左右に 偏ることなく、垂れ壁に対して垂直に後退するといえる。この移動 方向から、被験者が、提示された垂れ壁と、後方および側方壁面と
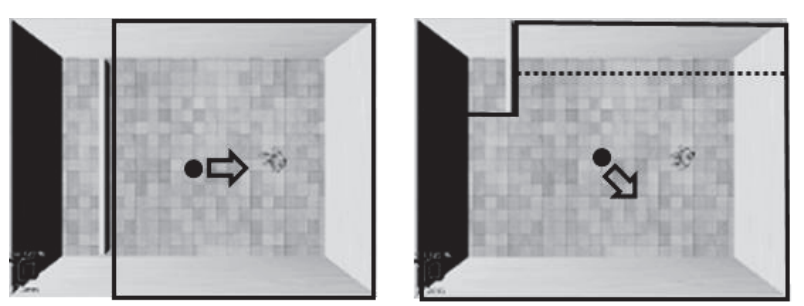

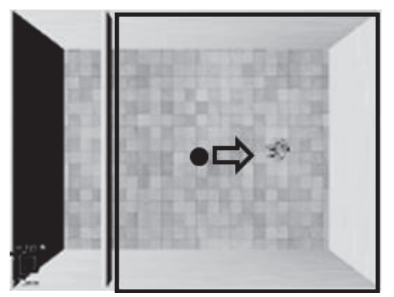

a. 幅 $3600 \cdot 5400 \mathrm{~mm}$

図 13 空間中心の移動から推測できる空間形状

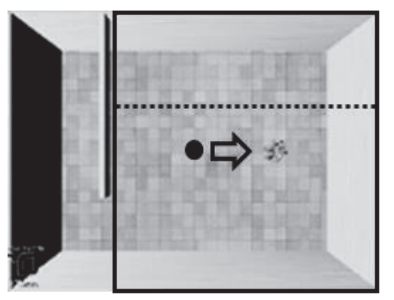

b. 右側壁に接した $1800 \mathrm{~mm} ・$ 幅 3600 
で囲まれた領域を、分節された一つ空間として認識し、その中心を 探り出すように行動していたことが推察される（図 13）。

実際、垂れ壁と後方壁面で囲われた領域の幾何学的な中心位置は、 基準空間の中央から $0.9 \mathrm{~m}$ 後退した位置となり、被験者の認識する空 間中心は、垂れ壁の高さが増すにつれてこの位置へ近づいていく。 ただし、幅 $3600 \mathrm{~mm}$ の垂れ壁では高さ 3000mm において、幅 $5400 \mathrm{~mm}$ の垂れ壁では高さ $2500 \mathrm{~mm}$ と高さ $3000 \mathrm{~mm}$ において、被 験者の認識する空間中心が、この幾何学的な中心をやや通り越して しまっている点には注意したい。壁面の木目テクスチャに対して、 垂れ壁が白色に近い灰色の膨張色であったため、垂れ壁からの圧迫 感が生じ、幾何学的中心よりも後退してしまう結果となったのでは ないかと考える。壁面や垂れ壁のテクスチャや色が、空間中心の認 識に与える影響については、今後の検証課題としたい。

続いて、(2)垂れ壁幅の影響の検証において見られた、前後方向と 左右方向の空間中心の移動量を統合し分析寸る。

まず、幅 $1800 \mathrm{~mm}$ の垂れ壁を片寄せて提示した場合、空間中心は、 提示された垂れ壁の中央軸から離れるように移動している。このこ とから、被験者が、垂れ壁の脇の空間を含めた L 字型の領域を、ひ とまとまりの空間として認識していたことが推察される（図 13）。

また、幅 3600mm の垂れ壁を片寄せて提示した場合、空間中心は、 左右に偏ることなく、垂れ壁に対して垂直に後退している。中央軸 上に垂れ壁を提示した場合と同じく、被験者が、垂れ壁と、後方お よび側方壁面とで囲まれた領域を、分節された一つ空間として認識 し、行動していたことが推察される（図 13）。この結果は、片寄せ した幅広の垂れ壁に対して、空間中心が、垂れ壁の中央軸に近づく ように斜めに後退していた実験 I の結果とは、異なるものである。 実験 I と実験 II で、片寄せした垂れ壁に対する空間中心の移動方 向が異なるのは、垂れ壁の前後方向の位置の違いに要因があるので はないかと考える。実験 I では、基準空間中央から前後方向一 1600mm後退した位置に、実験 II では、基準空間中央から前後方向 へ1800mm後退した位置に、垂れ壁が配置されている。すなわち、 実験 I と比べて実験 II では、垂れ壁奥の空間が $200 \mathrm{~mm}$ 浅いのである。 垂れ壁脇に見える空間の奥行きが浅いと、壁面や入隅など、垂れ 壁の脇の空間の形状が意識されやすくなり、脇の空間を含めたL字 型の領域をひとまとまりの空間として認識するようなるのではな いか。逆に、垂れ壁脇の空間の奥行きが深くなると、脇の空間の形 状が意識されづらくなり、垂れ壁と後方および側方壁面とで囲まれ た領域をひとつの空間として認識するようになるのではないか。矩 形空間の幅に対する垂れ壁の幅の割合に加えて、垂れ壁によって見 え隠れする奥の空間の深さが、空間中心の移動方向に変化を生じさ せている可能性について、今後の検証の余地が残された。

\section{6 まとめ}

本研究では、垂れ壁の寸法と配置が、矩形空間の心理的な中心位 置の認識にどのような影響を与えるのかを、没入型仮想環境技術を 用いた被験者実験を通して検証した。幅 $5400 \mathrm{~mm} \times$ 奥行 $7200 \mathrm{~mm} \times$ 天井高 $3000 \mathrm{~mm}$ の仮想の矩形空間に対する実験結果として、重要な ものを以下にまとめる。

・仮想の矩形空間内に、高さ $500 \mathrm{~mm}$ 以上の垂れ壁を提示すると、
矩形空間の心理的な中心位置は、垂れ壁がないときに比べて、垂 れ壁を正面にして後ろ向きに移動する。

・仮想の矩形空間内に垂れ壁を提示し、その高さを変化させると、 矩形空間の心理的な中心位置は、垂れ壁の高さが高くなるにした がって、さらに後ろに移動する。

・ 仮想の矩形空間内に垂れ壁を提示するとき、天井高 $3000 \mathrm{~mm}$ の矩 形空間に対して、垂れ壁の高さが $2000 \mathrm{~mm}$ を超えると、矩形空間 の心理的な中心位置は、それ以上後ろには移動しなくなる。

・仮想の矩形空間内に、矩形空間の幅よりも狭い幅の垂れ壁を、左 右どちらかの壁面に片寄せて提示寸ると、矩形空間の心理的な中 心位置は、垂れ壁を正面にして後ろ向きに移動するのと同時に、 左右にも移動する場合がある。

以上の実験結果より、垂れ壁の寸法や配置の変化によって、仮想 空間における空間の心理的な中心位置が定性的に移動することを、 明らかにすることができた。この空間の中心位置の移動が、空間形 状の認識の変化に起因して生じているものだとすると、垂れ壁によ つて、利用者が認識する空間の形状を任意に操作できる可能性が示 唆される。ただし本研究の結果は、あくまで仮想空間において限定 的なものあり、今後、現実の空間設計においてこの知見を援用して いくためには、現実空間における追加検証が必要不可欠であると考 える。

今回考案した、没入型仮想環境技術を用いて空間要素を変化させ ながら、空間の中心位置を被験者自身に評定させる実験手法は、空 間の形質や領域性を扱うさまざまな研究分野で援用されうる可能 性を持つ。現実の生活空間には、空間形状を変化させる様々な空間 要素が混在している。今回の実験結果の分析からも、壁面の色やテ クスチャが、空間の中心位置の認識に影響を与えることも示唆され た。また本研究では、空間の天井高さを $3000 \mathrm{~mm}$ に固定した上で、 垂れ壁の高さ寸法を変数として分析を行っているが、空間の高さが 他の值をとる場合には、垂れ壁の高さ寸法に加え、垂れ壁下端から 床面までの「あき」の寸法が、空間の中心位置に影響を与えること も考えられる。今後は、今回考案した実験手法をさらに発展させ、 垂れ壁を含むさまざまな空間要素、基準とする空間の高さや奥行寸 法、利用者の姿勢や向きといった、様々な条件が空間の認識にどの ような影響を与えているのかを詳細に検証していきたい。

\section{謝辞}

実験に参加していただいた被験者の方々、実験の準備に協力して いただいた方々に厚く御礼申し上げます。なお、本研究は、日本学 術振興会科学研究費補助金・若手研究 (A)「中心視と周辺視による 空間把握のメカニズム」(代表 : 吉岡陽介、平成 $22 \sim 26$ 年度、課題番 号22686056）の助成を受けたものである。

\section{参考文献}

1）内田茂：閉空間に対する感覚量に関する実験的研究1, 日本建築学会論文 報告集, No.282, pp.113-122, 1979.8 .

2）内田茂：閉空間に対する感覚量に関する実験的研究 2 , 日本建築学会論文 報告集, No.285, pp.117-125, 1979.11 .

3）込山敦司, 橋本都子, 初見学, 高橋鷹志: 室空間の容積と印象評価に関す る実験的研究, 容積を指標とした空間計画のための基礎研究その 1 , 日本 建築学会計画系論文集, Vol.1,No.496, pp.119-124, 1997.6. 
4）橋本都子, 込山敦司, 初見学, 高橋鷹志：室空間の容積と印象評価に関す る実験的研究, 容積を指標とした空間計画のための基礎研究その 2 , 日本 建築学会計画系論文集, No.508, pp.99-104, 1998.6.

5) 橋本都子, 込山敦司, 初見学, 高橋鷹志: 複数の在室者による室空間の容 積と印象評価に関する実験的研究, 容積を指標とした空間計画のための 基礎研究その3, 日本建築学会計画系論文集, Vol.3,No.525, pp.153-159, 1999.11.

6）込山敦司, 初見学: 床段差が室空間の心理的・機能的評価に及ぼす影響, 日本建築学会計画系論文集, No.495, pp.117-123, 1997.5 .

7）橋本雅好, 西出和彦, 高橋鷹志: 天井面・壁面が臥位での指示代名詞によ る領域分節に与える影響 : 臥位での指示代名詞による領域分節に関す る実験的研究 その 2 , 日本建築学会計画系論文集, No.567, pp.37-43, 2003.5 .

8）奥井治彦, 篠田竜也, 斎藤純一, 吉岡祥隆, 初見学: 片傾斜 - 段差天井の 知覚と心理的影響 : 空間認知構造に関する研究その 4 , 日本建築学会 大会学術講演梗概集. E, pp.739-740, 1989.

9) 大島芳彦, 佐々木龍郎, 嶋田洋平, 新堀学, 田島則行, 馬場正尊: 最高に 気持ちいい住まいのリノベーション図鑑，エクスナレッジ，p.179, 2012.

10）木村浩一：「拡散する家」新建築住宅特集 2009 年 6 月号, 新建築社, pp. 8 $8,2009$.

11）駒田剛司, 駒田由香:「アリウェイ戸越」新建築 2015 年 2 月号, 新建築社, p.88, 2015.

12）武井誠, 鍋島千恵：「構の郭」新建築 2013 年 12 月号, 新建築社, p. 86,20 13.

13）谷尻誠：「上大須賀の家」新建築 2009 年 12 月号, 新建築社, p.179, 2009.

14）メジロスタジオ：「千歳船橋の住宅」新建築住宅特集 2009 年 02 月号, 新 建築社, p.108, 2009.

15）妹島和世：「葉山の小屋」新建築 2010 年 05 月号, 新建築社, p. $52,2010$.

16）大野力, 山本愛：株式会社ドワンゴ/本社来客・カフェエリア/納入事例/コ クヨファニチャー, 入手先〈http://www.kokuyo-furniture.co.jp/solutio n/space/works/post.php?link=jirei〉（参照日25/11/2015）

17）佐々木龍一, 奥村梨枝子: Sasaki Architecture converts Japanese dis co into offices with floating walls, 入手先〈http://www.dezeen.com/ 2015/04/28/sasaki-architecture-japanese-disco-warehouse-conversionoffices-floating-walls-tokyo/ $\rangle$ （参照日25/11/2015）

18）若山鉄兵, 大井尚行：「まとまり」という概念を用いた屋外空間の知覚に 関する研究 : 大学キャンパスを事例として, 日本建築学会研究報告. 九 州支部. 2, 環境系, No.40, pp.281-284, 2001.

19）若山鉄兵, 大井尚行：「まとまり」及び「中心」という概念を用いた屋外 空間の知覚に関する研究：ヴォリューム的空間知覚と点的視対象によ る知覚構造について, 日本建築学会研究報告. 九州支部. 2, 環境系, No. 41, pp.117-120, 2002.3.
20）吉澤望, 稲本淳平, 平手小太郎, 大山能永, 小野浩史：バーチャルリアリ ティを用いた住環境呈示システムにおける実空間再現性の検討, 被験者 実験による明るさ感, 空間の大きさ感, 寸法感,現実感の検証, 日本建築学 会計画系論文集, No.550, pp.87-93, 2001.12.

21）小野浩史, 青島智恵, 森川泰成, 吉澤望, 平手小太郎：提示装置の違いに よる現実感・没入感・設計ツールとしての有効性の検証, バーチャルリア リティを用いた住環境提示システムにおける実空間再現性の検討 その 2 , 日本建築学会環境系論文集, No.583, pp.57-63, 2004.9 .

22）小野浩史，平手小太郎：被験者属性・提示装置の違いに着目した空間認識 に関する基礎的研究，バーチャルリアリティを用いた住環境提示システ ムにおける実空間再現性の検討 その 3 , 日本建築学会環境系論文集, No. 593, pp.103-109, 2005.7.

23）横井梓, 齋藤美穂：VR空間における心理的影響の評価に関する検討，大 型スクリーンを用いた居住空間シミュレーションにおけるVR空間の感 性評価, 日本建築学会環境系論文集, Vol.78,No.683, pp.1-7, 2013.1.

24）大野隆造, 青木宏文, 添田昌志：CG画像と模型画像の合成による視覚シ ミュレーション，日本建築学会技術報告集，No.12，pp.135-138，2001. 1.

25）片山めぐみ，小松崎敏紀，添田昌志，大野隆造：歩行動作と連動する視環 境シミュレータを用いた距離知覚に関する研究, その 1 シミュレータの 開発と有効性の検証, 日本建築学会大会学術講演梗概集. D-1, pp.849850, 2001.9.

26）小松崎敏紀，片山めぐみ，添田昌志，大野隆造：歩行動作と連動する視環 境シミュレータを用いた距離知覚に関する研究, その 2 経路上の視覚情 報と距離知覚の関係, 日本建築学会大会学術講演梗概集. D-1, pp.851852, 2001.9 .

27）大野隆造, 片山めぐみ, 小松崎敏紀, 添田昌志: 歩行動作と連動する視環 境シミュレータを用いた距離知覚に関する研究, 日本建築学会計画系論 文集, No.550, pp.95-100, 2001.12.

28）添田昌志，米本由佳，大野隆造：視覚的な意識の広がりと街路空間との 評価の関係, その 1 空間の物理的特性と心理評価との関係, 日本建築学 会大会学術講演梗概集. D-1, pp.813-814, 2002.8 .

29）野村淳二：建築におけるVRシミュレーション, 建築雑誌, Vol.110,No.1 381, pp.32-33, 1995.12 .

30）小野原靖, 岸本達也：HMDとジャイロセンサーを組み合わせたインタラ クティブなVRシステムによる街路空間評価の可能性, 日本建築学会技 術報告集, No.20, pp.279-284, 2004.12.

31）小場則夫，小泉光司，岸本達也：VRを用いた日本橋中央通りにおける建 物形態と景観の印象分析, 個性的な街路景観創出を目的としたVRを用 いた景観分析その 2 , 日本建築学会計画系論文集, Vol.73,No.626, pp.79 5-802, 2008.4. 


\title{
INFLUENCES OF SIZES AND POSITIONS OF HANGING WALL ON PERCEPTION OF SPATIAL CENTER IN VIRTUAL REALITY SPACE
}

\section{Hayato TAKAHASHI* and Yohsuke YOSHIOKA**} \\ * Grad. Stud., Graduate School of Engineering, Chiba University \\ ** Assoc. Prof., Division of Architecture and Urban Science, Graduate School of Engineering, Chiba University, Dr.Eng.
}

There are spaces of various spatial configurations, living room, workspace and classroom. Each of them is adapted to the intended use. This study is focused on psychological boundaries that affect the specific spatial configuration. The perception of spatial configuration limits the behavior and scope of activities in physically and psychologically. Intentionally arranging the elements that produce psychological boundaries in space divide a certain space into several small spaces, it is possible to use in various purposes.

We propose the hanging wall as the element that produces psychological boundaries. We perform experiment in the method for immersion of subject into virtual reality space with wide view head mounted display (HMD). While the experiments, subjects walk to the subjective central position in virtual rectangular space. Four cameras are installed at each corners of real laboratory to track the movement of subjects and acquire the coordinate data. In addition, the angle sensor of three axis (InertiaCube 2+) is equipped in HMD, acquires the angle of rotation of subject's head. To tune subject's coordinate data and angle of rotation data to the image of virtual environment on HMD, subjects can walk and look around in virtual environment.

This study verified how sizes and positions of hanging wall influence on perception of spatial center in virtual rectangular space, through experiments with technology of immersive virtual environment. The summary of the important experimental results of virtual rectangular space of width $5400 \mathrm{~mm} \times$ depth $7200 \mathrm{~mm} \times$ ceiling height $3000 \mathrm{~mm}$ is as follows.

1.) Subjective central position in virtual rectangular space could move backward from hanging walls by presenting hanging walls of height of $500 \mathrm{~mm}$ or more, in comparison with by the presenting no hanging wall.

2.) Subjective central position in virtual rectangular space would move back more from hanging walls as the increasing heights of the hanging walls.

3.) Subjective central position in virtual rectangular space wouldn't move backward any more from hanging walls by exceeding $2000 \mathrm{~mm}$ high of the hanging walls in rectangular space of ceiling height $3000 \mathrm{~mm}$.

4.) Subjective central position in virtual rectangular space would move backward and right or left from hanging walls, when presented hanging walls that are narrower than width of rectangular space are put aside toward the right and left wall.

The above experimental results revealed that subjective central position in virtual rectangular space qualitatively move by changing sizes and positions of hanging wall. Assuming that this movement of spatial central position caused by change in perception of spatial configuration, it suggests the possibility that perception of spatial configuration could be operated by presenting hanging walls.

Also, this devised experimental method that evaluated spatial central position by subject own self with changing spatial elements using technology of immersive virtual environment, it has possibility that various fields of research dealing with spatial trait and region would reference. There are various spatial elements that change perception of spatial configuration in the real living space. These experimental results suggested that textures and colors of walls influenced on perception of spatial central position. Henceforth further development on this devised experimental method, is necessary to verify how various spatial elements including hanging wall influence on user's perception of space. 